\title{
UROCZYSTE POSIEDZENIE POLSKIEGO TOWARZYSTWA TEOLOGICZNEGO
}

Dnia 6 czerwca 1962 r., oubyło sie w auli Krakowskiego Seminarium Duchownego uroczyste zebranie Polskiego Towarzystwa Teologicznego poświęcone złotemu jubileuszowi kapłańskiego JE. ks. arcbpa E. B a ziaka oraz ks. ks. profesorów: ks. infułata F. IM a c h a y a, ks. prof. Wł. W i c h r a. ks. T. Długosza oraz ks. prał. IM áslińskiego. Zebranie zagaił Prezes P. T. T. k.s. prof. Wł. S m e reka, witając wszystkich jubilatów i członków Towarzystwa z JE. ks. arcbpem Baziakiem na czele. Ks. Prezes w. swoim przemówieniu podkreślił wielkie zasługi wszystkich jubilatów dla nauki teologicznej w Polsce i dla naszego Towarzystwa, składając im na końcu serdeczne życzenia i szczere gratulacje. Z kolei al. Niewie$\mathrm{dzi}$ il wygłosił okolicznościową deklamację, po ozym ks. prał. Al. Klawe k miał zasadniczy referat pt. 40-lecie Polskiego Towarzystwa Teologicznego, fakty - wspomnienia. Dostojny referent przypomnial wszystkim datę 16 maja 1922 r., kiedy to Rada Wydziału Teologicznego UJK we Lwowie postanowiła powołać do życia P.T. T., którego celem było kształcić zawodowo duchowinych i czuwać nad rozwojem nauk teologicznych w Polsce. Praca ta rozwijała się dobrze dzięki współpracy profesorów z poszczególnych Wydziałów Teologicznych Uniwersytetów Jana Kazimierza we Lwowie, Uniwersytetu Jagiellońskiego w Krakowie, Uniwersytetu Stefana Batorego i Uniwersytetu Warszawskiego. P.T.T. miało także swoje pisma jak np. P'rzegiad Teologiczny, Biblioteka Religijna, Polonia Sacra i wychodzący do dziś a założony w $1948 \mathrm{r}$. przez ks. prof. Al. K la w k a Ruch Biblijny $i$ Liturgiczny. Po referacie JE. ks. arcbp B a zi a k podziękował w swoim imieniu i w imieniu swoich kolegów w kapłaństwie za serdeczne życzenia, zachęcając wszystkich do dalszej owiocnej pracy i naukowej i wydawniczej z zakresu nauk teologicznych. Piękne ramy dla całej uroczystości stworzył chór alumnów Krakowskiego Seminarium Duchownego, który pod kierunkiem ks. prof. S a pety wykonał na początku i na końcu zebnania kilka utworów wokalnych.

Kraków

Red.

\section{ŚP. DOM BERNARD CAPELLE OSB}

19 października 1961 r. zmarł w opactwie benedyktyńskim w Mont César w Belgii jego długoletni opat $\rightarrow$ O. Bernard Capelle OSB. Postać wybitna na polu nauki i ruchu liturgicznego, dla których zmarły położył wielkie zasługi. Oto co o nim pisze w 68 numerze czasopismo duszpastersko-liturgicznego La Maison-Dieu dyrektor tego kwartalnika Aimé-Georges Martimort.

Paweł Capelle urodził się w Namur w 1884 r. i - jak niejeden benedyktyn - przeszedł do życia monastycznego dopiero po kilkuletniej pracy w szeregach kapłanów świeckich, diecezjalnych. W tych pierwszych latach - 1912-1918 - był wikarym w Gembloux, lecz miał już za sobą studia w Rzymie, w czasie których zdobył doktorat z teologii i doktorat z nauk biblijnych. W swej pracy doktorskiej nad tekstem łacińskiego psałterza w Afryce, daje sie już pcznać jako przyszły liturgista, łączący w so- 
bie znajomość Biblii i literatury patrystycznej. O jego powolaniu zakonnym zadecydowało opatrznościowe zdarzenie. W 1911 r., jeszcze w czasie pobytu $\mathrm{w}$ Rzymie, zachorował $\mathrm{i}$ w tym czasie zapoznał się z przyniesionymi mu "dla rozrywki“ pierwszymi ulotkami Questions Liturgiques, Revue reservée au clergé et aux religieux, wydawanymi przez opactwo Mont César przy współpracy kilku świeckich księży. Każdy numer zawierał artykuł Dom Lamberta Beauduin'a, cmawiającego $z$ entuzjazmem nowrości budzącego się ruchu liturgicznego. Piotr Capelle był tak wstrząśnięty tym odkryciem, że w wiele lat później mawiał jeszcze, że był to dlań moment decydujący. Po powrocie do Belgii przebył jednak jeszcze owe 12 lat na wikariacie w Gembloux, po czym wstapił do opactwa Benedyktynów w Maredsous, gdzie otrzymal wraz z habitem imię - Bernarda. Sławny Dom Marmion powierzył mu tam pieczę nad biblioteką i kierownictwo nad publikacją Revue Bénédictine, czym go ostatecznie skierował ku pracy naukowej. Innym opatrznościowym zdarzeniem było wybranie go w 1928 r. na opata w Mont César przez mnichów, którzy go poznali swego czasu, w czasie jednego $\mathrm{z}$ jego tam pobytów w charakterze profesora, co zadecydowalo o jego specjalizacji w historii liturgii, gdyż tu właśnie ukazywało się czasopismo Questions Liturgiques et Paroissiales i odbywaly się doroczne Tygodnie Liturgiczne.

Dom Capelle poświęcił całą swą wiedzę i gorliwość liturgii, a służył jej słowem i piórem. Sława jego rychło przekroczyła granice opactwa i Belgii. Każdy numer Questions zawierał jego artykuły. Ponadto przewodniczył $\mathrm{w}$ Tygodniach Liturgicznych i prowadził wykłady. 12 grudnia 1935 r. Pius XI udzielił mu audiencji i wyraził w wymownych słowach swą aprobatę dlu ruchu liturgicznego ${ }^{1}$. W 1936 r. Dom Capelle objął katedre historii liturgii na Wydziale Teologicznym w Louvain i zajmowal ja przez 10 lat. W 1946 r. nawiązał współpracę z paryskim Centre de Pastorale Liturgique, która przetrwała aż do ostatnich niemal chwil jego życia. Proszony był o udział we wszystkich obradach redakcyjnych czasopisma La Maison-Dieu, domagano się od niego często artykułów, głosił wykłady podczas sesji wersalskich. W $1950 \mathrm{r}$. mianowany został konsultorem Kongregacji Obrzędów, gdzie kilkakroć wygłaszał swe bardzo cenione opinie na temat reformy liturgicznej, jaką Stolica Apostolska rozpoczęła. Wreszcie we wrześniu 1960 r. został członkiem Papieskiej Komisji Liturgicznej, przygotowującej przyszły Sobór Powszechny, co nie tylko było zaszczytem, ale zobowiązywało do żmudnej pracy, której Dom Capelle podjął się mimo ciężaru swego wieku i męczących podróży.

Odszedł nie dokończywszy swego dzieła. Nie dokończył też publikacji zbioru swych licznych artykułów. Po tomie I.: Traveaux Liturgiques de Doctrine et d'Histoire, (I. Doctrine, Louvain, Mont César, 1955, s. 285, in $8^{\circ}$ ), tom II jest $\mathrm{w}$ druku, a zbierze się jeszcze materiał i na tom III. Są to artykuły, które ukazały się $w$ następujących wydawnictwa.ch:

1 Questions Liturgiques et Paroissiales. 21, 1936, s. 4 i 134-137. 
Questions Liturgiques et Paroissiales, Cours et Conférences des Semaines Liturgiques, Revue Bénédictine, Revue de l'Histoire Ecclésiastique, Recherches de Théologie Ancienne et Médiévale, La Maison-Dieu, Journal of Theological Studies - by wymienić tylko najpoważniejsze pozycje. Będzie to kiedyś potężna summa, wypracowywana stopniowo, gdyż autor tylko rzadko kiedy porywał się na syntezy, wiơząc czające się w nich niebezpieczeństwo.

W inwentarzu bibliograficznym ${ }^{2}$ Dom Capelle wyróżnić można cztery grupy dzieł. Sam stawiał na czele swe przyczynki do teologii liturgii, z których złożył się tom I zbioru jego prac. Dodać doń trzeba sprawozdanie, jakie wygłosił w 1956 r. na Międzynarodowym Kongresie w Assyżu, na temat Théologie Pastorale des Encycliques Mystici Corporis et Mediator Dei i małą książeczkę Pour une meilleure Intelligence de la Messe. Natrafiał nieraz na trudności w wyrażaniu myśli, lecz ponieważ prawie zawsze pisał o tekstach przeznaczonych dla szerolkiego ogółu, więc język literacki i brak terminów technicznych zacierały czasem precyzję, jaka by się w nich chciało znaleźć. Jednak po bliższej analizie studia te wnoszą światło do licznych, delikatnych kontrowersji, jak pojęcie kultu lub odróżnienie między tym ca liturgiczne a nieliturgiczne.

Za to jego dzieło jako historyka zawiera nadzwyczaj jasne i decydujące intuicje. Wykorzystał on swą bystrość i prawie niezawodny zmysł krytyczny na całym polu historii liturgii. Dwie grupy prac wyodrębniają się tu $\mathrm{w}$ szczególności: studia nad Miszą św. i ankiety na temat kultu maryjnego. Te ostatnie stały się nadzwyczaj aktualne przy definiowaniu dogmatu Wniebowzięcia NMP. Dwukrotnie dokonal ich syntezy w I tomie Maria i w Eglise en Prière.

Dom Capelle rzucił żywe światło na historię Mszy św. Analizował i komentował antyczne anafory, których tekst oryginalny i datowanie ustalał z całą pewnością. W ten spasób przywrócił wartość anaforze Serapiona, św. Bazylego i papirusowi Der Balizeh, wykorzystując odkrycia i prace papyrologów. Badał także obrzędy i modlitwy współczesnej Niszy św. rzymskiej: Kyrie, Gloria, Kolekty, Credo, Prefacje, Secrety, Communicantes, Qui pridie, łamanie Chleba, łączenie postaci, które zawdzięczają mu sensacyjne wyjaśnienia, a przyjęte zostały przez uczonych tak jednogłośnie, że stały się dziś powszechnie uznane. Nie ma już nikogo. np. kto by nie znał litanii papieża Gelazego, spopularyzowanej przez muzykę do tekstu francuskiego.

Dom Capelle dochodził do rezultatów swej pracy przez powolną i szczegółową krytykę literacką i filologiczną. Nie wahał się przerobić krytyczne wydanie tekstów głównych lub dyskutowanych, jak np. Gloria in excelsis lub list Inocentego I do Decentiusa.

2 W sprawie jego publikacji od 1934-1953 r. patrz: Universit'e Catholique de Louvain, Bibliographie Académique, t. 7, vol. I. Louvain 1954, s. 394-398, od 1954-1959 patrz: Questions Liturgiques et Paroissiales, Tables Générales, t. 1, Louvain 1959, s. 11-13. 
Ta sama metoda pozwoliła mu śledzić ewolucję różnych form liturgicznych, jak np. antyfony In Paradisum, odróżnić różnoroddność liturgii kościołów Rzymu, zidentyfikować autorów różnych modlitw - jest to, powiedzmy, czwarta grupa jego publikacji. Czy analizował Exxultet paschalny, czy oracje w sakramentarzach, zawsze jego olbrzymia wiedza patrystyczna poddawała mu uderzające zbliżenia z dziełami św. Ambrożego, papieży Leona św. Gelazego, Wigiliusza i św. Grzegorza. Późniejsze prace Chavass'a, Pomares'a lub Lang'a wykazały jak słuszne były poglądy Dom Capelle na sakramentarze, w przeciwieństwie do awanturniczych hipotez, które uważał za swój obowiązek zwalczać ile razy się pojawiały.

Dom Capelle, proponując naukową interpretację tekstów i obrzędów, stwierdzał z radością, że przyczynia się do odnowy liturgicznej, gdyż stworzony był do nauki i nauczania, nauczania jasnego, precyzyjnego, konkretnego, którego jego uczniowie nigdy nie byli syci. Na międzynarodowych zebraniach liturgistów zachowywał przezorną rezerwę $\mathrm{w}$ stosunku do propozycji reformistycznych. Nie była to w jego wypadku małoduszność lub konserwatyzm: $\mathrm{i}$ on także umiał $\mathrm{w}$ danym wypadku wysunąć propozycję uporządkowania obrzędów ${ }^{3}$ i ujawniał wiele zmysłu duszpasterskiego. Lecz obawiał się - i słusznie - zacieśniania liturgii w sztuczne systemy i by jej nie pozbawiono, na skutek niezręcznych manipulacji, skarbca modlitw Ojców Kościoła. Mlodlitwy te przeżywal osobiście całą swą kontemplacyjną duszą, z zawsze młodzieńczą żarliwością. Pamiętamy jeszcze jego komentarz podczas jednego $\mathrm{z}$ Tygodni Liturgicznych $\mathrm{w}$ Louvain, nad rytuałem pogrzebowym. Nie był świadom tego, że ujawnił swe własne rozmyślanie na temat miłosierdzia bożego i ziemi obiecanej.

Kraków

Przyswoiła

FELICJA ŻUROWSKA

3 Fraction et Commixtion, art. W La Maison-Dieu, 35, 1953, s. 79-94, Le Vendredi Saint, art. w La Maison-Dieu, 37, 1954, s. 93-117. 